\title{
O INSTITUTO JURÍDICO DA SEGURANÇA HIIDRICA E A NECESSIDADE DE UM AJUSTE NORMATIVO E JURISPRUDENCIAL
}

THE LEGAL INSTITUTE OF WATER SECURITY AND THE NEED FOR NORMATIVE AND JURISPRUDENTIAL ADJUSTMENT

\section{EL INSTITUTO JURÍDICO DE LA SEGURIDAD HIDRICA Y LA NECESIDAD DE UN AJUSTE NORMATIVO Y JURISPRUDENCIAL}

\section{José Irivaldo Alves Oliveira Silva'}

\section{José Rubens Morato Leite²}

Licença CC BY:

Artigo distribuído sob os termos Creative Commons, permite uso e distribuição irrestrita em qualquer meio desde que o autor credite a fonte original.

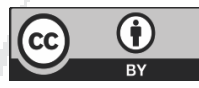

\begin{abstract}
Resumo: A Era do Antropoceno tem na crise ambiental sua principal característica, destacando-se a crise de água como sendo a mais grave. Dessa forma, faltam instrumentos jurídicos que forneçam aos tribunais, ao ministério público e às demais instituições jurídicas uma maior compreensão da crise hídrica vivenciada. Por isso, o presente artigo traz como problema a ausência de um instituto jurídico da segurança hídrica que dê conta da complexidade ambiental, não se restringindo apenas à falta de água, uma vez que não basta ter água, ela precisa ser própria para os múltiplos usos. O objetivo central é justamente apresentar o contexto de crise ambiental e hídrica e os elementos fundantes para elaboração de uma definição jurídica mais precisa de segurança hídrica. Para isso, realizou-se pesquisa bibliográfica, com acesso a dados secundários em documentos e jurisprudência dos tribunais. Verificou-se que os tribunais ainda não compreendem a complexidade da crise hídrica.
\end{abstract}

Palavras-chave: Água; Segurança Hídrica; Mudança Jurisprudencial; Segurança Jurídica.

\footnotetext{
1 Professor Adjunto da Universidade Federal de Campina Grande, Doutor, Pós-doutorando em Direito Ambiental pela Universidade Federal de Santa Catarina, e-mail: irivaldo.cdsa@gmail.com

2 Professor Titular dos cursos de Graduação e Pós-Graduação em Direito da Universidade Federal de Santa Catarina - UFSC; Pós- Doutor pela Unversidad Alicante, Espanha 2013/4; Pós-Doutor pelo Centre of Environmental Law, Macquarie University - Sydney - Austrália 2005/6; Doutor em Direito Ambiental pela UFSC, com estágio de doutoramento na Faculdade de Direito da Universidade de Coimbra.
} 
Abstract: The main feature of the Age of the Anthropocene is the environmental crisis, in particular, the water crisis. There is a lack of legal instruments that provide the courts, public prosecutors and other legal institutions with a better understanding of this water crisis. This article therefore presents the problem of absence of a legal institute of water security that accounts for the environmental complexity, not being restricted only to the lack of water, since it is not enough merely to have water; it must also be suitable for multiple uses. The central objective is to present the context of environmental and water crisis, and the founding elements, in order to elaborate a more precise legal definition of water security. For this purpose, bibliographic research was carried out, with access to secondary data in documents and jurisprudence of the courts. It was found that the courts still do not understand the complexity of the water crisis.

Keywords: Water; Water security; Jurisprudential change; Legal security.

Resumen: La Era del Antropoceno tiene su característica principal en la crisis ambiental, destacando la crisis del agua como la más grave. Por lo tanto, hay una falta de instrumentos legales que proporcionen a los tribunales, fiscales y otras instituciones legales una mejor comprensión de la crisis del agua experimentada. Por lo tanto, el presente artículo presenta como un problema la ausencia de un instituto legal de seguridad del agua que tenga en cuenta la complejidad ambiental, y no se limite solo a la falta de agua, ya que no es suficiente tener agua, sino que debe ser adecuado para el uso múltiple. El objetivo central es precisamente presentar el contexto de la crisis ambiental y del agua y los elementos fundamentales para elaborar una definición jurídica más precisa de la seguridad del agua. Para ello, se realizó una investigación bibliográfica, con acceso a datos secundarios en documentos y jurisprudencia de los tribunales. Se encontró que los tribunales aún no entienden la complejidad de la crisis del agua.

Palabras clave: Agua; Seguridad del agua; Cambio jurisprudencial; Seguridad jurídica.

\section{INTRODUÇÃO}

Já foi bastante repisado o contexto ambiental global atual, um contexto de crises, sendo a crise ambiental a principal delas, uma vez que ameaça a sobrevivência de todas as formas de vida do Planeta. Vivencia-se um momento de inflexão mundial com avanços e retrocessos em face da legislação ambiental, em que se indica uma tendência à flexibilização da mesma, no caminho de uma menor proteção ambiental, e um aumento da força do paradigma do desenvolvimento/ crescimento em detrimento de um paradigma ecológico.

Nesse diapasão, surge outra crise, que se faz parecer separada da primeira, mas que, no entanto, tem ampla relação com a crise ambiental: a crise hídrica. Essa está, inegavelmente, na ordem do dia. Nesse trabalho, preferir-se-á classificá-la como crise das águas, tendo em vista que a primeira expressão remete a uma 
Novos Estudos Jurídicos

questão muito próxima de um debate eminentemente técnico e que, portanto, tem uma solução exclusivamente técnica, o que levaria a pensar que a resolução pode ser simples e desvencilhada da crise ambiental, nutrida por uma visão cartesiana, que não se adequa mais com os problemas sistêmicos de um período classificado como pós-modernidade e uma nova era chamada de Antropoceno.

Entende-se que, para uma situação complexa, é preciso pensar em conceitos que abarquem essa complexidade, sendo um princípio para se refletir sobre a organização de uma política pública com ações efetivas. Nessa direção, pretendese abordar nesse ensaio elementos que possam dar subsídios para a construção de um modelo conceitual jurídico de "segurança hídrica", a formação de um instituto que balize decisões, considerando que na legislação pátria não consta nenhum dispositivo que objetivamente traga esse conceito, havendo uma lacuna que dificulta, não impossibilita, a compreensão da importância da efetividade de uma política de águas, impondo aos magistrados, ao Ministério Público, bem como aos advogados uma dificuldade a mais que é juntar as "peças" de um complexo e intrincado "quebra-cabeças" para a compreensão em face do que significa segurança hídrica.

Dessa forma, os objetivos desse artigo são trazer à baila uma análise do termo "segurança hídrica", suas contradições e confluências, no sentido de juntar elementos que possam auxiliar num conceito que deva ser incorporado ao texto legal, viabilizando a regulação de uma política de águas, bem como estabelecer parâmetros para isso, e balizamento, em consonância com a política ambiental, dando uma orientação para uma política ecológico-sistêmica numa simbiose entre meio ambiente e água, que muitos tentam separar, dando alicerce para um Estado de Direito Ecológico, que deve ser formado sobre uma nova base ética de proteção da natureza e, portanto, num cruzamento com o direito humano ao meio ambiente. Para atingir esses objetivos, lançou-se mão do método dedutivo, amplo levantamento bibliográfico e análise documental. 


\section{A CRISE HÍDRICA E SUA INTERRELAÇÃO COM A CRISE AMBIENTAL}

\subsection{ELEMENTOS DAS CRISES}

Falar em crise remete sempre a momentos de dificuldades, de desarmonia, de desestabilização, portanto não se trata de algo positivo, tranquilo, que se possa dizer que há controle sobre os seus pressupostos, longe, ainda, de uma visão apocalíptica, mas tratando de momentos e circunstâncias que promovem, especialmente, desequilíbrios ambientais e sociais. A crise também expressa momentos de esgarçamento, de exaurimento, de teste do funcionamento das bases da sociedade e de suas instituições.

Como mencionado anteriormente, o momento que se vivencia atualmente é emblemático na medida em que agentes públicos buscam desconstruir um processo traumático de crises e, dentre elas, a ambiental, que expressa o resultado de um processo de exploração profundo, além das capacidades do Planeta. Como afirma Alier ${ }^{3}$ e Leff ${ }^{4}$, os efeitos dessa crise ambiental serão mais nefastos para os mais vulneráveis dentre as camadas da sociedade, portanto não se pode falar dessa crise como sendo uma crise exclusivamente ambiental separada, portanto, de uma dimensão social.

Os efeitos dessa crise ambiental e social já podem ser sentidos, por exemplo, nos movimentos migratórios de comunidades em virtude das mudanças climáticas, seja pela incidência de fenômenos da natureza muito fortes, como tsunamis, furacões, avanço das águas do mar, escassez de água. É preciso, talvez, uma análise menos compartimentalizada da crise, uma vez que uma crise, um distúrbio ambiental, poderá afetar diversas áreas da sociedade mundial, saúde, educação, clima, economia, enfim, essas crises podem estar relacionadas. E isso se expressa também numa fragmentação dos direitos ambientais e direitos humanos, como atesta Bollier et al5. São sinais desse processo de crise:

3 ALIER, J. M. O ecologismo dos pobres: conflitos ambientais e linguagens de valoração. São Paulo: Contexto, 2007.

4 LEFF, H. Racionalidade ambiental: a reapropriação social da natureza. Rio de Janeiro: Civilização Brasileira, 2006.

5 BOLLIER, D., WESTON, B. H. Green Governance ecological survival, human rights, and the law of the commons. New York: Cambridge University Press, 2013. 


\section{1) o risco e uma modernidade reflexiva passam a ser uma tônica:}

é preciso pontuar que o risco sempre existiu, não é algo exclusivo de uma época, porém ao que parece seus efeitos foram ampliados com a aproximação da modernidade 6 . Uma das grandes dificuldades apontadas nessa seara diz respeito especialmente ao controle desses riscos, aumentado com o passar do tempo, e a quantificação de seus danos ${ }^{7}$, e um clamor por parâmetros de assegurassem um ambiente de segurança e certezas. É interessante destacar aqui um conceito de risco dado por Veyret ${ }^{8}$ que diz o seguinte; "a palavra designa, ao mesmo tempo, tanto um perigo potencial quanto sua percepção e indica uma situação percebida como perigosa na qual se está ou cujos efeitos podem ser sentidos". Portanto, risco não é uma situação lúdica, mas que pode ser sentido em seus múltiplos efeitos, principalmente quando se leva em consideração um contexto de declínio da base material do Planeta. Uma característica desse período é justamente a presença da incerteza como característica dos tempos contemporâneos, ficando muito mais difícil analisar, perceber esses fenômenos sem uma perspectiva mais integrativa9 ${ }^{9}$, que suplante uma visão cartesiana.

2) o exaurimento de recursos naturais: esse é um ponto delicado que caracteriza bem os dilemas que compõem o que se conhece como risco; a destruição da base material da Terra é uma realidade cada vez mais presente, principalmente para os mais vulneráveis. Uma das consequências nessa seara é justamente a migração forçada de comunidades em virtude, por exemplo, das mudanças climáticas, formando o que se conhece como refugiados ambientais, ou como se refere Cavedon-Capdeville ${ }^{10}$, deslocados ambientais. Esses fluxos de pessoas têm se intensificado e exigido um tratamento específico, uma proteção específica num estatuto próprio, frente às normas internacionais ${ }^{11}$, causado

6 MOTTA, R. Sociologia de risco: globalizando a modernidade reflexiva. In. Sociologias, Porto Alegre, ano 11, no 22, jul./dez. 2009, p. 384-396.

7 MENDES, J. M. Ulrich Beck: a imanência do social e a sociedade do risco. In Análise Social, 214, I (1.), 2015.

8 VEYRET, Y. Os riscos: o homem como agressor e vítima do meio ambiente. São Paulo: editora Contexto, 2007, p. 25.

9 PORTO, M. F. de. Uma ecologia política dos riscos. Rio de Janeiro: editora Fiocruz, 2007.

10 CAVEDON-CAPDEVILLE, F. de S. O Projeto de Convenção de Limoges sobre o Estatuto Internacional dos Deslocados Ambientais. In JUBILUT, L. L. et al. (Orgs). Refugiados ambientais. Roraima: Editora da UFRR, 2018.

11 CAVEDON-CAPDEVILLE, F. S. Jurisprudência ecologizada nas cortes de direitos humanos: contribuições para a ecologização dos direitos humanos. In LEITE, J. R. M. A ecologização do direito ambiental vigente. Rio de Janeiro: Lumen Juris, 2018. 
por desastres naturais, ou não, mudanças climáticas, esgotamento de recursos naturais ${ }^{12}$. É uma realidade cada vez mais frequente, acontecendo de certa maneira como resultado da ausência de fatores que assegurem minimamente a sobrevivência. A hiperexploração dos recursos naturais tem suas consequências nefastas para as comunidades em geral, atingindo mais uns do que outros, tendo um potencial desestabilizador notadamente em regiões que têm $\operatorname{conflitos}^{13}$, isso tem uma ação direta sobre as cidades, nas metrópoles que padecem de planejamento. Esses efeitos podem ser mediatos ou imediatos.

Orozco ${ }^{14}$ deixa claro que se está à sombra de um novo Leviatã, num contexto de assalto à ciência e de uma república industrial, ou seja, há um processo de desinvestimento em produção de conhecimento e uma diretriz equivocada de superexploração de recursos naturais no sentido de reforçar uma ideia de desenvolvimento baseada numa indústria forte, pujante e crescente. Parece que cada vez mais uma ciência aplicada à tecnologia e a serviço da indústria terá mais apelo, notadamente, para captar recursos. Nesse processo podem ser citados os transgênicos como uma das maneiras de interferência em arranjos e dinâmicas naturais, numa perspectiva em que ciência, tecnologia e indústria estão caminhando juntas ${ }^{15}$.

Uma análise apenas focada num esgotamento dos recursos naturais sob uma perspectiva interna é limitada, uma vez que deixa de se enxergar uma perspectiva geopolítica bastante forte no que se refere à extração desses recursos naturais. Bruckmann ${ }^{16}$ aborda de modo claro a função geopolítica da exploração de recursos naturais, como ferro, manganês, nióbio, grafeno, água, enfim, uma riqueza incomensurável que demonstra a dilapidação do patrimônio

12 BIAZATTI, B. de O., PEREIRA, L. D. D. Aspectos Principiológicos acerca da Necessidade de Proteção dos "Refugiados Ambientais": Por uma Nova Hermenêutica do Sistema Jurídico Internacional. In JUBILUT, L. L. et al. (Orgs). Refugiados ambientais. Roraima: Editora da UFRR, 2018.

13 FELIX, R. B. Bangladesh: Vulnerabilidade Ambiental e a Vida Humana. In JUBILUT, L. L. et al. (Orgs). Refugiados ambientais. Roraima: Editora da UFRR, 2018.

14 OROZCO, J. L. Esperando a Trump: Los antecedentes históricos del "nuevo viraje" norteamericano. México: Universidad Nacional Autónoma de México, 2017.

15 FERREIRA, H. S. Desvendando os organismos transgênicos: as interferências da sociedade de risco no Estado de Direito Ambiental. Rio de Janeiro: Forense Universitária, 2010.

16 BRUCKMANN, M. Recursos naturales y la geopolítica de la integración sudamericana. Instituto Perumundo; Fondo Editorial J.C.Mariátegui, 2012. 
Novos Estudos Jurídicos

da humanidade, ou como Isla ${ }^{17}$ menciona categoricamente, que a destruição da floresta para o plantio de culturas que serão em sua maioria exportadas. $O$ custo ambiental e o custo social representam um verdadeiro subsídio ecológico para o mercado internacional que não é compatibilizado ou compensado.

3) a informação e a deformação: com uma incerteza crescente acerca da veracidade das informações, fruto dos tempos de hiper risco, o aumento na efemeridade da informação vem potencializar esse contexto. O fluxo frenético de informações tornou mais complexa a maneira como se depuram as informações verdadeiras das falsas, uma vez que são diversas as fontes de informação e cada indivíduo passou a ser um gerador de conteúdo nas redes sociais.

O que chama atenção é quando se está abordando informações que tratam de conteúdos muito específicos, especializados, como organismos transgênicos, mudança climática, segurança alimentar, desmatamento, escassez de água, saneamento básico, entre tantos outros relacionados com a vida e a proteção ambiental do Planeta. Ferreira ${ }^{18}$ menciona um detalhe que tem relação direta com a qualidade da informação, uma vez que ela considera que existe um esforço de se ocultar o risco na sociedade contemporânea, havendo um processo de tentativa de amenizar possíveis efeitos, sendo uma das diferenças entre a primeira modernidade e a segunda, uma vez que nessa última fica mais dócil ocultar os riscos, as fragilidades dos modelos simbólicos de comunicação e regulação dos riscos fica muito à mostra, há dificuldade potencial em se esconder da esfera pública.

Os mecanismos de negação institucional já não conseguem mais deixar distante do público possível danos que possam ser causados, por exemplo, por alguma substância, os efeitos acabam sendo muito perceptíveis, isso é característico de uma sociedade de risco. Ademais, o aparato científico é fundamental para corroborar, ou não, com o reforço das informações que apoiem, ou assegurem, a ausência, ou a presença, de risco em face de alguma conduta ou substância que se apresenta.

17 ISLA, A. The "greening" of Costa Rica: women, peasants, indigenous people and the remaking nature. Canadá: University of Toronto Press, 2015.

18 FERREIRA, H. S. Desvendando os organismos transgênicos: as interferências da sociedade de risco no Estado de Direito Ambiental. Rio de Janeiro: Forense Universitária, 2010. 


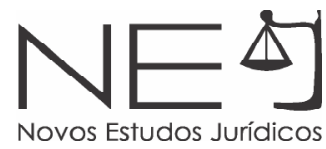

4) governança do meio ambiente: outro fator que é complexificado no contexto de uma segunda modernidade nessa sociedade de risco é a forma como será possível gestionar os recursos, a qual continua sendo uma questão constante nas discussões e nas ações para otimizar o uso dos elementos da natureza. Cunharse a expressão "desenvolvimento sustentável" em diversas dimensões, inclusive na jurídica, auxiliou sobremaneira a uma mudança direcionada a melhoria dessa gestão dos elementos da vida no Planeta. Entretanto, ao que parece, encontra-se insuficiente para responder hoje a iminência dos efeitos das mudanças na Terra.

Governança tem um sentido muito ligado ao exercício de governo, por exemplo, o Programa da Nações Unidas para o Desenvolvimento (PNUD) define governança como sendo o exercício da autoridade econômica, política e administrativa de modo a gerenciar todos os setores de um país ${ }^{19}$. O Banco Mundial em uma de suas publicações reconhece governança como sendo a maneira pela qual os oficiais públicos e as instituições adquirem e exercem a autoridade para operacionalizar as políticas públicas e conceder bens e serviços públicos ${ }^{20}$. Wolf et al. ${ }^{21}$ deixam claro que o sentido de governança enfatiza um Estado capaz, que é responsável perante os cidadãos e opera sob o império da lei. Ao que parece o maior problema para que se desenvolva uma governança da natureza é a necessidade de instauração de um novo modelo, baseado no resgate dos saberes locais e no diálogo de saberes, como afirma Leff $^{22}$. Isso poderia propiciar sair de um Direito Ambiental do Dano para um Direito Ambiental Ecológico ${ }^{23}$.

19 UNDP. Governance for Sustainable Human Development, A UNDP Policy Document. UNDP, New York, 1997.

20 World Bank. Strengthening World Bank Group Engagement on Governance and Anticorruption. Joint Ministerial Committee of the Boards of Governors of the Bank and the Fund on the Transfer of Real Resources to Developing Countries, Washington, DC, 2007.

21 WOLF, A. T., STEFANO, L. de, SVENDSEN, M., GIORDANO, M. STEEL, B. S., BROWN, B. Water governance benchmarking: concepts and approach framework as applied to Middle East and North Africa countries. In Water Policy 16, 1121-1139, 2014.

22 LEFF, H. Diálogos de saberes, saberes locales y racionalidad ambiental en la construcción social de la sustentabilidad. In SÁNCHEZ, A. L. Governabilidad y desarrolho sustentable: miradas múltiples. México: UNAM, 2012.

23 LEITE, J. R. M., SILVEIRA, P. G. BETTEGA, B. O Estado de Direito para a natureza: fundamentos e conceitos. In Dinnebier, Flávia França (Org.). Estado de Direito Ecológico: Conceito, Conteúdo e Novas Dimensões para a Proteção da Natureza./ Flávia França Dinnebier (Org.); José Rubens Morato Leite (Org.); - São Paulo : Inst. O direito por um Planeta Verde, 2017; ARAGÃO, A. O Estado de Direito Ecológico no Antropoceno e os limites do Planeta. In Dinnebier, Flávia França (Org.). Estado de Direito Ecológico: Conceito, Conteúdo e Novas Dimensões para a Proteção da Natureza./ Flávia França Dinnebier (Org.); José Rubens Morato Leite (Org.); - São Paulo : Inst. O direito por um Planeta Verde, 2017. 
O Direito pode conferir um aparato teórico e um instrumental fundamentais para a elaboração de uma nova governança do meio ambiente no contexto de crise ambiental, na medida em que ele for capaz de se adequar aos novos valores, princípios e os incorporem ao processo legislativo e até nas sentenças e nos acórdãos dos tribunais.

Entretanto, a despeito dessa perspectiva, é importante registrar que nem todos os teóricos acreditam numa perspectiva de crise catastrófica, daí se cite David Harvey ${ }^{24}$, teórico marxista contemporâneo, em que ele discorda veementemente de uma visão extremada da crise ambiental, afirmando que verdadeiramente há uma crise, porém é preciso analisá-la do ponto de vista político e econômico, uma vez que a crise não está dada, ela é formada por uma relação de retroalimentação em que o "(...) capital é um sistema ecológico em constante funcionamento e evolução, no qual natureza e capital são constantemente produzidos e reproduzidos". A despeito da necessidade de uma nova governança para lidar com um contexto de sociedade de risco, de crise ambiental, a crise em si, segundo ele, não se sustenta pelos seguintes fatos ${ }^{25}$.

o capital tem resistido às premonições apocalípticas do mundo, apesar de todos os danos causados pelo capitalismo, para ele, numa tese plausível, crescendo o potencial do capital, crescerá também a destruição da natureza;

a natureza está interiorizada na circulação e na acumulação de capital, sendo o fluxo monetário uma variável ecológica, e a transferência de nutrientes através de um ecossistema também deve constituir um fluxo de valor;

o capital transformou a questão ambiental num grande negócio, tornandose numa estratégia de acumulação;

há um capitalismo do desastre, um capitalismo que se alimenta da crise, o capital pode perfeitamente continuar a circular e se acumular sob condições de catástrofe ambiental.

24 HARVEY, D. 17 contradições e o fim do capitalismo. São Paulo: Boitempo, 2016, p. 230.

25 HARVEY, D. 17 contradições e o fim do capitalismo. São Paulo: Boitempo, 2016. 


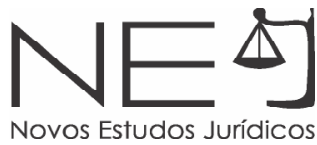

Essa crítica precisa de Harvey é importante para que se desconstrua uma visão romantizada que possa ainda existir acerca da proteção da natureza num contexto de crise ambiental, o que pode influenciar numa juridicização da segurança hídrica.

5) processo de afastamento e fragilização do Estado: Esse processo de afastamento do Estado de questões estratégicas é cíclico, dependerá obviamente de quem está ditando a agenda de políticas públicas e da influência de agentes externos. A atuação estatal é fundamental para que se impulsionem reformas que consolidem e fortaleçam uma política pública ambiental. Isso é bem o diagnóstico planetário.

Parece que há um contrassenso estabelecido, no entanto o que se verifica é que mesmo que a esfera privada afirme categoricamente que o Estado deve ser afastado para que ela atue melhor, o que se verifica é a necessidade cada vez maior do Estado, que vai beneficiar também a esfera privada. Dardot e Laval26 são categóricos em afirmarem que há um grande engano em prensar que a inciativa privada deseja um desengajamento efetivo do Estado, sendo o mesmo cada vez mais necessário para mediar as relações.

Dessa forma, tem-se aqui cinco "pistas" que caracterizam a atualidade, um momento envolto no esgotamento do meio ambiente e, principalmente, na ineficiência do Estado em administrar "remédios" eficazes a esse processo de dilapidação da base material do Planeta, sendo uma tensão constante entre Estado, população e o capital, e ao que parece esse último está vencendo ou conseguindo se impor em relação aos demais.

\subsection{CRISE DAS ÁGUAS}

Independente de um processo de mudanças climáticas, parece factível afirmar que há um processo de crise no acesso à água, ou seja, sua distribuição não chega a todos como se busca modernamente com o princípio da universalização desse bem, e quando chega não se tem confiança em relação à sua qualidade.

26 DARDOT, P., LAVAL, C. A nova razão do mundo: ensaios sobre a sociedade neoliberal. São Paulo: Boitempo, 2016. 
Passou-se de um acesso para subsistência no campo, para uma água canalizada no ambiente urbano, o que representou uma mudança substancial na compreensão da água como bem comum e bem público. A formação das cidades também foi um fenômeno que, certamente, produziu impactos na relação entre seres humanos e água.

Aswathanarayana ${ }^{27}$, quando aborda a situação de crise vivenciada atualmente pela humanidade como algo catastrófico, inclui a mudança de padrões de consumo de água como um divisor de água, uma vez que se passou de um consumo de subsistência, para um consumo em grande escala, citando o caso da Índia e o da China, que são emblemáticos, em que o primeiro aumentou em 30 anos a quantidade de tubulações de água de 3 milhões para 23 milhões, e a diminuição do nível de água no segundo em cerca de 20 metros nos últimos 20 anos. É importante destacar que, segundo o mesmo autor, esse aumento no consumo não se baseia naquele essencialmente doméstico, mas um uso industrial e agrícola, que é responsável por cerca de $80 \%$ do total.

Portanto, uma das chaves de análise das causas da crise é o modelo econômico adotado, levando-se em consideração que o consumo de água nos países industrializados é cerca de 30 vezes maior do que em países em desenvolvimento. Shiva ${ }^{28}$, a partir da análise dessa questão na Índia, por sua vez, apresenta uma forte causalidade entre escassez de água potável e o modelo de desenvolvimento adotado, num contexto de uma intensa industrialização, utilização de agrotóxicos nas plantações, poluição, entre outros fatores. Entretanto, para que se tenha um arcabouço protetivo, ou que haja uma relevância jurídica, visto que a importância social já estava patente, só em 2010 o direito à água foi votado na Assembléia Geral da ONU como direito humano ${ }^{29}$.

Entretanto, segundo Aswathanarayana, há um processo de diminuição do uso da água certamente por causa do aprimoramento da consciência em relação

27 ASWATHANARAYANA, U. How to do with less water. In Aswathanarayana, U. (Coord.). Food and water security. London: Taylor \& Francis, 2007.

28 SHIVA, V. Las guerras del agua: privacización, àcontaminación y lucro. Mexico: Siglo XXI editores, 2007.

29 BULTO, T. S. Muito familiar para ignorar, muito novo para reconhecer: a situação do direito humano à água em nível global. In CASTRO, J. E., HELLER, L., MORAIS, M. da P. O direito à água como política pública na América Latina: uma exploração teórica e empírica. Brasília: IPEA, 2015. 
à finitude desse bem, assim assevera através da adoção de parâmetros diante de um processo de escassez de água.

Na maioria dos países industrializados, o uso da água está se tornando menor. Por exemplo, os EUA usam muito menos água por pessoa e menos água no total do que há vinte e cinco anos. Em alguns casos, o uso da água é reduzido por causa da escassez, mas na maioria dos casos, os países deliberadamente mudaram suas economias, para permitir que a água seja usada com mais eficiência. No caso do Japão, durante o período de 1965 a 1989, a quantidade de água necessária para produzir um milhão de dólares em bens caiu de cinquenta milhões de litros para treze milhões de litros. Um padrão semelhante de diminuição no consumo per capita de água tem sido observado na Finlândia, partes da Austrália, grande parte da Europa e até Hong Kong. O economista ganhador do Prêmio Nobel Simon Kuznets é de opinião que, no caso dos países industrializados, à medida que as tecnologias amadurecem e a eficiência melhora, elas se tornam mais conscientes da importância da preservação da qualidade do meio ambiente, que tem como consequência o uso os recursos naturais, incluindo a água, de maneira mais sustentável. (Tradução livre) $)^{30}$

Esse panorama de crise, muito além de marcar um momento histórico de esgarçamento humano, tem como significado maior que os sistemas que compõem o grande sistema Terra está acima de sua capacidade de sustentação das demandas humanas que crescem cada vez mais, numa visão de crescimento, crescimento e crescimento, descolado ainda de uma visão de justiça ecológica e de justiça social, isto é, sem ter como meta primeira o equilíbrio com as demandas de todas as classes da sociedade, dividindo-se de forma justa os ônus e os benefícios do uso e do acesso à base material do Planeta. Dessa forma, crêse que se tem 4 (quatro) modalidades de crise das águas:

30 In most industrialized countries, water use is becoming less. For instance, USA uses far less water per person, and less water in total, than it did twenty-five years ago. In some cases, water use is reduced because of scarcity, but in most cases, countries deliberately changed their economies, to enable water to be used more efficiently. In the case of Japan, during the period, 1965-89, the amount of water needed to produce a million dollars' worth of goods went down from fifty million litres to thirteen million litres. A similar pattern of decrease in per capita consumption of water has been observed in Finland, parts of Australia, much of Europe, and even Hong Kong. The Nobel Prizewinning economist Simon Kuznets is of the view that in the case of the industrialized countries, as technologies mature and efficiency improves, they become more conscious of the importance of the preservation of the quality of environment, which has the consequence of using the natural resources, including water, in a more sustainable manner. (Texto original). ASWATHANARAYANA, U. How to do with less water. In Aswathanarayana, U. (Coord.). Food and water security. London: Taylor \& Francis, 2007, p. 72. 
1) Crise de quantidade - a população mundial cresce e caminha para mais de 7 bilhões de indivíduos, o que, notadamente, demanda mais água, e sabe-se que essa está distribuída espacialmente de forma irregular, não sendo possível garantir que todos tenham acesso a esse elemento fundamental para a manutenção da vida, o que não se quer dizer aqui que essa irregularidade geográfica seja a causadora dessa quantidade incompatível com as demandas da humanidade. É preciso, também, analisar essa crise sob o prisma político, pois a má distribuição é proveniente do modelo político implementado. A gestão da água de forma compatível com as necessidades vitais ou prioritárias é uma dimensão essencial.

2) Crise de qualidade - outra crise importante é a poluição cada vez maior dos mananciais, das nascentes, dos cursos de rios, córregos, mares, comprometendo ainda mais a qualidade da água, que é essencial, pois não adiantará quantidade se não houver qualidade, e aí tem-se uma agricultura poluidora das águas superficiais e subterrâneas com o uso crescente de agrotóxicos, e a produção animal e a mineração, que contribuem na poluição das águas com metais pesados, por exemplo, a produção de resíduos nas cidades e sua disposição de forma incorreta, que também auxilia nessa contaminação.

3) Crise de acesso - Mesmo que haja quantidade e qualidade, há uma questão a ser resolvida, que está sendo apenas mitigada, que é o acesso, a distribuição para todos da água. Essa é uma questão que tem um componente político preponderante, que não se circunscreve numa questão apenas técnica, de tecnologia aplicada a soluções de acesso à água.

4) Crise de ocupação do solo - essa é uma crise presente nas cidades que crescem como aglomerados humanos por excelência e, especificamente, em cidades da América Latina, África e Ásia, cuja tônica é a falta de planejamento na espacialização das edificações em geral, não havendo um zoneamento acerca do que pode ou não ser construído e onde, de modo a provocar o menor potencial de danos, especificamente, em se tratando de considerar o ciclo urbano da água, impondo limites para as construções, proibindo-se a edificação, por exemplo, em áreas de preservação permanente, nas margens de córregos, nos mangues, 


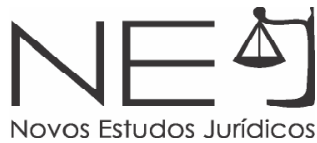

nas áreas de recarga dos aquíferos, enfim, delimitando claramente os locais que podem sofrer a intervenção humana.

Defende-se aqui nesse ensaio que a crise das águas tem esses 4 elementos que foram classificados de crises que são fundamentais para se pensar um conceito jurídico para "segurança hídrica". Nesse diapasão, a escassez versus a distribuição se apresentam como elementos chaves para que haja um parâmetro jurídico que estabeleça o que vem a ser a segurança hídrica.

Mais recentemente, a questão da água ganhou escopo e a ONU a colocou como o sexto Objetivo do Desenvolvimento Sustentável (ODS), que está assim grafado: "Assegurar a disponibilidade e gestão sustentável da água e saneamento para todos"31. A partir desse objetivo, que expõe um grande desafio que se possui mundialmente, com mais de 2,5 bilhões de pessoas que não possuem banheiros, e $70 \%$ de toda a água é utilizada para irrigação ${ }^{32}$, é interessante chamar atenção para uma das grandes dificuldades de concretização desse direito humano e objetivo do desenvolvimento sustentável, apontado por Castro ${ }^{33}$, a concretização da cidadania em relação ao paradoxo entre universalizar a água e o saneamento num mundo em que a água já se consolida como mercadoria.

Além de uma escassez da água, causada por chuvas irregulares, falta de investimento público, má distribuição hídrica, soma-se o processo em larga escala de mercantilização da água ${ }^{34}$, implicando na transformação da água de um bem comum, em que todos poderiam usufruir sem restrição para um bem claramente econômico. Ao mesmo tempo em que a mercantilização da água pode servir de fator limitante para seu acesso e, portanto, talvez a diminuição de sua utilização, também não implica numa diminuição das injustiças na distribuição. Essa crise ganha contornos mais preocupantes em virtude do distanciamento entre essa crise das águas e a crise ambiental como se fossem coisas isoladas.

31 https://nacoesunidas.org/conheca-os-novos-17-objetivos-de-desenvolvimento-sustentavel-da-onu/

32 https://nacoesunidas.org/conheca-os-novos-17-objetivos-de-desenvolvimento-sustentavel-da-onu/

33 CASTRO, J. E. O acesso universal à água é uma questão de democracia. In Boletim Regional, Urbano e Ambiental no 15, Julho/Dezembro 2016a.

34 CASTRO, J. E. Água e democracia na América Latina. Campina Grande: EDUEPB, 2016b. 


\section{FORMANDO O CONCEITO DE SEGURANÇA HÍDRICA}

Tanto Giddens ${ }^{35}$ como Beck ${ }^{36}$ possuem uma visão acerca da modernidade, a primeira baseada numa modernidade reflexiva, a segunda numa modernidade constituída por uma sociedade de risco. Porém, ambos elegem a questão ambiental como resultado ou consequência nesse cenário de modernidade. A modernidade reflexiva propõe a possibilidade de uma (auto)destruição criativa para toda uma era: aquela da sociedade industrial, na qual o sujeito da destruição não seria a crise, mas a vitória da modernização ocidental, com a presença de sistemas peritos, especialistas, enfim, um conjunto de elemento racionalizadores.

Beck ${ }^{37}$ coloca a modernidade sob o prisma da reflexividade, sendo o risco o elemento permanente dessa realidade, não devendo o mesmo ser confundido com o perigo, que realizado resulta num desastre, terminado o percurso perigoso ${ }^{38}$, sendo o risco, pelo contrário, algo que abre dada situação e bifurca o percurso da história de forma imprevisível, aproximando-se, a priori, da sorte.

Em sua visão, os riscos são gerados a partir do desenvolvimento das forças produtivas, em nível mais avançado, como o lixo nuclear, bem como substâncias tóxicas; a divisão e o aumento dos riscos surgem em situações de perigo, que prejudicam pessoas que não contribuíram em nada para essa situação, bem como pode ser gerado o que chamou de efeito bumerangue, voltando para aqueles que produziram o risco; a expansão dos riscos não gera diminuição da potencialidade da lógica capitalista, pelo contrário, eleva-o; os riscos da modernidade acabam sendo um grande negócio; há um novo significado político do saber, devendose analisar o potencial político de uma sociedade de risco, talvez uma sociologia e uma teoria do surgimento e difusão do saber dos riscos; os riscos reconhecidos socialmente possuem um conteúdo explosivo. Adequa-se a essa abordagem a questão das águas e sua contaminação.

Esse momento de risco vivido, segundo Beck e Giddens, tem como mediadora a ciência, que se coloca como possibilidade de percepção a enxergar

35 GIDDENS, A. As conseqüências da modernidade. São Paulo: Editora da UNESP, 1991.

36 BECK, U. La sociedad del riesgo: hacia una nueva modernidad. Barcelona, Paidós, 2006.

37 BECK, U. La sociedad del riesgo: hacia una nueva modernidad. Barcelona, Paidós, 2006.

38 LENZI, C. L. Sociologia ambiental: risco e sustentabilidade na modernidade. São Paulo, Bauru: Edusc, 2006. 


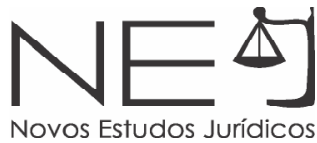

essas situações de risco, de modo imperfeito, sendo muitas vezes incapaz, a ciência, de reconhecer os riscos e os problemas que ela mesma possui. A ciência pode ser encarada como uma das protetoras de uma contaminação global de pessoas e natureza. Há uma construção científica e social dos riscos.

É importante afirmar que Beck $^{39}$ não descarta a possibilidade de se ter a ciência como uma fonte de soluções. Entretanto, ela pode gerar uma posição ambivalente na institucionalidade ambiental, de um lado a ciência está diretamente ligada ao desenvolvimento da sociedade industrial, responsável direta pela hiperprodutividade, dando base para aqueles que defendem o consumismo em detrimento da proteção ambiental; de outro a ciência pode ajudar a enxergar os riscos ambientais presentes em nosso meio, bem como pode ser artífice de uma cegueira sistemática.

Fala-se aqui de risco e perigo, por se compreender sua relação de proximidade em face da expressão "segurança", ou seja, num contexto de uma sociedade permeada por riscos é possível ter-se segurança hídrica? Inicialmente, talvez seja necessário problematizar a expressão "segurança". Seria possível estabelecer parâmetros que denotem segurança? Para isso anteriormente já se partiu do pressuposto de que há um contexto de crises e que dentre essas há a crise das águas e a crise ambiental, que estão imbricadas na sua essência, ou seja, em vez de se falar que a crise ambiental é mais ampla, e o é na verdade, é mais interessante para a abordagem que se propõe aqui falar-se em inter-relacionamento de crises ou mesmo numa visão sistêmica.

Como produto dessas crises, o ordenamento jurídico ainda está pautado numa lógica mecanicista, cartesiana, que precisa, talvez, migrar para uma compreensão mais sistêmica. Para isso, pode auxiliar entender como a natureza sustenta a vida, os processos biológicos, químicos e físicos dos organismos que lutam pela sobrevivência e que de certo modo estão interligados. Parece que a evolução da natureza por bilhões de anos tem algo a ensinar à humanidade em termos de organização e dê indicações de como se deve extrair as necessidades para a sobrevivência dos seres humanos. A questão é como a lei sofrerá essa

39 BECK, U. La sociedad del riesgo: hacia una nueva modernidad. Barcelona, Paidós, 2006. 
influência, especificamente a lei ambiental, requerendo-se uma transformação profunda na noção do que a lei é.

$\mathrm{Na}$ compreensão de Boyd $^{40}$, é fundamental essa visão sistêmica para que haja uma mudança da perspectiva da lei ambiental, por exemplo, para que haja a consolidação de um sistema de proteção ambiental que vise a um Estado de Direito Ecológico. Então, seria importante compreender como se dão os princípios de organização da natureza, o que implicaria numa alta carga de pesquisa, e de interação entre lei e ciência. Parece que a possibilidade mais interessante seria buscar a instituição de um arcabouço legal que caracterizasse o comum.

O que Capra e Matei $^{41}$ propõem é justamente um diálogo entre lei e ecologia, como algo imprescindível para a mudança de curso na sobrevivência da humanidade, ou como aponta Leff ${ }^{42}$, para uma necessária reapropriação da natureza, uma ressignificação da mesma para a humanidade.

\subsection{SEGURANÇA VERSUS RISCO}

Ao que parece, o que mais se deseja na atualidade é segurança em todos os sentidos, seja contra atos de violência em geral, contra a destruição da natureza, no trânsito, na saúde, nas transações financeiras, no consumo, é o bem mais almejado por todos e extremamente valioso no capitalismo. Pagamse altos valores por segurança, inclusive é o grande fundamento das empresas de seguro, nas quais você tem tranquilidade, mesmo numa sociedade de riscos. Porém, pelo que foi abordado até aqui, a sociedade contemporânea tem como característica basilar a existência de riscos, em contrapartida tem-se a promessa constante, bem como a busca por circunstâncias de segurança.

40 BOYD, D. R. The Rigths of Nature: A Legal Revolution that Could Save the World. Toronto: ECW Press, 2017.

41 CAPRA, F.; MATTEI, U. The Ecology of Law. Okland: BK. 2015.

42 LEFF, H. Racionalidade ambiental: a reapropriação social da natureza. Rio de Janeiro: Civilização Brasileira, 2006. 


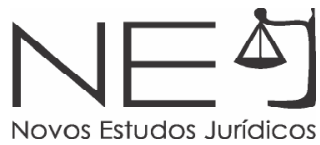

Torna-se difícil pensar-se em segurança numa sociedade marcada pela imprevisibilidade, pelo efêmero, uma sociedade líquida ${ }^{43}$, sendo forçoso pensar a dificuldade em cunhar-se qualquer conceito referente à segurança. Segundo Ribeiro ${ }^{44}$ : Outra característica peculiar aos nossos tempos reside na imprevisibilidade desses riscos, o que se explica pelo incomparável avanço científico e tecnológico, que, embora deixe desconcertadas as pessoas comuns, são planejados pelos es- pecialistas. Mas ao mesmo tempo, geram efeitos colaterais que não poderiam ser imaginados sequer pelos idealizadores de tais conquistas.

Então a ciência não teria o condão de oferecer à humanidade uma vida sem riscos, ao passo que pode oferecer certa segurança e que efeitos colaterais podem ocorrer, como se fosse a "bula" de remédio, ou a própria quimioterapia que tem como finalidade primaz a cura do câncer, entretanto com muitos efeitos colaterais. Tem-se aí uma ambivalência própria desse momento vivido, em que há pontos positivos e negativos em relação aos avanços tecnológicos, em relação à própria industrialização. Inclusive é possível pensar isso em relação à mineração, por exemplo, que oferece à humanidade diversas benefícios em diversas áreas, porém é responsável por uma verdadeira devastação dos ecossistemas, notadamente os mananciais de água que abastecem a vida na Terra.

Essa segurança num ambiente de risco presencia a busca por uma neutralização ou minimização desses riscos, num equilíbrio entre confiança e risco aceitável. Dessa forma se poderia atingir a segurança tão almejada. Porém, a incerteza e a imprevisibilidade ainda pairam, busca-se incorporar nas argumentações jurídicas a compreensão de um risco aceitável que, portanto, é possível um dano aceitável e que certas atividades têm um risco que pode ser controlado. É aceitável que o risco seja um indicador fundamental para a segurança, tendo como finalidade a necessidade de se mensurar o risco para se quantificar o nível de segurança. Parece que se chega à compreensão de que a segurança não poderá ser considerada absoluta numa sociedade de risco.

43 BAUMAN, Z. Modernidade e ambivalência. Rio de Janeiro: Jorge Zahar, 1999.

44 RIBEIRO, R. L. Globalização, Sociedade de Risco e Segurança. Revista de Direito Administrativo, Rio de Janeiro, v. 246, p. 267-287, set. 2007, p. 272. ISSN 2238-5177. Disponível em: <http://bibliotecadigital.fgv.br/ojs/ index.php/rda/article/view/41660>. Acesso em: 12 Fev. 2019. doi:http://dx.doi.org/10.12660/rda.v246.2007.41660. 
Para se quantificar os níveis de segurança, diversas entidades criam protocolos, normativas que visam justamente orientar as ações humanas, seja na construção de barragens, de edifícios, pavimentação de ruas, saneamento básico, ou mesmo para se aferir o grau de confiança de consumo e uso de água dos diversos mananciais existentes, sejam superficiais ou subterrâneos. Esses critérios também são utilizados para se orientar o padrão de segurança para a água ou segurança hídrica.

\section{SEGURANÇA HÍDRICA: UM INSTITUTO JURÍDICO FUNDAMENTAL PARA O ESTADO DE DIREITO ECOLÓGICO}

A utilização da expressão "Estado de Direito Ecológico" não se trata de mera mudança de terminologias, mas a implementação de outro olhar sobre os bens ambientais, em que esses seriam considerados vitais para a sobrevivência da humanidade e que teriam uma característica fundamental, a indicação da proteção à natureza como genuíno direito humano, uma vez que sem essa base natural não seria possível a vida humana na Terra, nem uma vida saudável com qualidade compondo uma dignidade humana mínima ${ }^{45}$. É preciso avançar de um Estado de dano ambiental para um Estado de efetividade das políticas públicas ambientais.

Aragão ${ }^{46}$ aponta o Direito como uma ciência social fundamental para a mudança de paradigma, não se tratando apenas da formulação de leis para não serem cumpridas, ou seja, a formulação de conceitos e a inserção desses no texto legal devem ser provenientes de uma base teórica e empírica com alicerces firmes para que se possa implementar e daí promover uma mudança de paradigma. Leite et al. ${ }^{47}$, por sua vez, apontam que o aprofundamento da crise ambiental e a entrada na era do Antropoceno reclamam uma maior proteção

45 CAVEDON-CAPDEVILLE, F. S. Jurisprudência ecologizada nas cortes de direitos humanos: contribuições para a ecologização dos direitos humanos. In LEITE, J. R. M. A ecologização do direito ambiental vigente. Rio de Janeiro: Lumen Juris, 2018.

46 ARAGÃO, A. O Estado de Direito Ecológico no Antropoceno e os limites do Planeta. In Dinnebier, Flávia França (Org.). Estado de Direito Ecológico: Conceito, Conteúdo e Novas Dimensões para a Proteção da Natureza./ Flávia França Dinnebier (Org.); José Rubens Morato Leite (Org.); - São Paulo: Inst. O direito por um Planeta Verde, 2017

47 LEITE, J. R. M., SILVEIRA, P. G. BETTEGA, B. O Estado de Direito para a natureza: fundamentos e conceitos. In Dinnebier, Flávia França (Org.). Estado de Direito Ecológico: Conceito, Conteúdo e Novas Dimensões para a Proteção da Natureza./ Flávia França Dinnebier (Org.); José Rubens Morato Leite (Org.); - São Paulo: Inst. O direito por um Planeta Verde, 2017. 


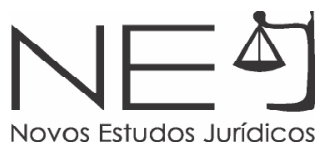

da natureza, daí a necessidade de se fortalecer a partir de um entendimento em torno de um Estado de Direito voltado para a dimensão ecológica, do contrário a existência estará comprometida.

Cavedon-Capdeville ${ }^{48}$ apresenta com agudeza e precisão que é necessário perceber que o princípio constitucional da dignidade humana está fincado na necessária proteção da natureza para que se tenha um ambiente de qualidade para que os direitos humanos possam ser concretizados, pois do contrário esses não poderão ser realizados. É fato que o atual modelo de Estado não é eficaz nesse processo de proteção da natureza. É sob essa mudança de paradigma que se deve formular novos conceitos e institutos que possam auxiliar o direito na formulação de saídas paradigmáticas que apontem para um Estado que tenha a real capacidade de proteger os bens ambientais.

Em se tratando das águas existentes no Planeta, é necessário uma proteção sistêmica, uma vez que esses mananciais de água são vitais para a sustentação da vida na Terra. A legislação brasileira, por seu turno, não trata acerca da segurança hídrica, não conceitua e não estabelece parâmetros orientadores para a mesma. É importante notar que a legislação pátria trata como prioridade de abastecimento, no caso de escassez de água, a dessedentação animal e o consumo humano (Lei 9.433, art. 1, inc. III). A palavra "segurança" é tratada na lei, que estabelece a Política Nacional de Recursos Hídricos, apenas quando mencionada a "segurança de barragens".

Escassez é o parâmetro tratado apenas uma vez na lei, ficando um vácuo quando se trata de estabelecer patamares mínimos para assegurar a dignidade humana, aí claramente incluído o que é necessário para a sobrevivência, mas uma sobrevivência em sentido mais lato, que se conecte com o significado de ecossistema. Dessa forma, o estabelecimento de um único patamar de medição, a "escassez", parece ser limitado diante de uma era do Antropoceno, que aponta para a necessidade de medidas cada vez mais claras e eficazes para a proteção dos bens ambientais. Isso tem impacto direto nas decisões judiciais e na atuação de órgãos como o Ministério Público, os quais ficam sem uma clareza mínima do

48 CAVEDON-CAPDEVILLE, F. S. Jurisprudência ecologizada nas cortes de direitos humanos: contribuições para a ecologização dos direitos humanos. In LEITE, J. R. M. A ecologização do direito ambiental vigente. Rio de Janeiro: Lumen Juris, 2018. 
que vem a ser "segurança hídrica", ou passam a fazer ilações que não contribuem para um ambiente de segurança jurídica. Para se ter uma ideia, fazendo-se uma busca nos repositórios de decisões e jurisprudências dos tribunais federais, incluindo-se o Supremo Tribunal Federal (STF) e o Superior Tribunal de Justiça (STJ), não é possível encontrar nenhuma menção à expressão "segurança hídrica". No entanto, a expressão encontrada nas decisões dos tribunais federais é a "escassez hídrica", que se conecta com o sentido daquela inserção no diploma legal da PNRH, de simples falta de água. Dessa forma, está-se tratando a falta de água como algo simples, porém ela advém de fenômenos complexos que estão acontecendo com mais frequência.

O que se defende aqui é a necessidade de um conceito de segurança hídrica, que gere um instituto, que esteja de acordo com o contexto atual de mudanças climáticas e que seja abrangente, incorporando o sentido de escassez hídrica e assumindo indicadores necessários para manter o equilíbrio mínimo ecossistêmico. Veja-se a, seguir exemplo de decisão do STJ que não apresenta a terminologia de segurança hídrica, referindo-se apenas à escassez hídrica.

..EMENTA: ADMINISTRATIVO. REGIME JURÍDICO DAS ÁGUAS SUBTERRÂNEAS E AQUÍFEROS. COMPETÊNCIA AMBIENTAL. FORNECIMENTO DE ÁGUA. FONTE ALTERNATIVA. POÇO ARTESIANO. ART. 45 DA LEI 11.445/2007. CONEXÃO À REDE PÚBLICA. PAGAMENTO DE TARIFA. ART. 12, II, DA LEI 9.433/1997. CRISE HÍDRICA E MUDANÇAS CLIMÁTICAS. 1. Trata-se, originariamente, de ação que visa à declaração de ilegalidade de decreto estadual e portaria, de modo a autorizar o recorrido a utilizar fonte alternativa de água (poço artesiano), obstando a aplicação de multas pecuniárias e a lacração do poço. A sentença de procedência parcial foi mantida pelo Tribunal a quo. REGIME JURÍDICO DAS ÁGUAS SUBTERRÂNEAS 2. No que concerne ao domínio das águas, o art. 20, III, da CF/1988 prevê, entre os bens da União, "os lagos, rios e quaisquer correntes de água em terrenos de seu domínio, ou que banhem mais de um Estado, sirvam de limites com outros países, ou se estendam a território estrangeiro ou dele provenham, bem como os terrenos marginais e as praias fluviais". Já o art. 26, I, da CF/1988, entre os bens dos Estados, inclui "as águas superficiais ou subterrâneas, fluentes, emergentes e em depósito, ressalvadas, neste caso, na forma da lei, as decorrentes de obras da União", evidentemente submetidas aos mesmos critérios e exceções espaciais fixados no art. 20, III. 3. Quanto à competência legislativa, o art. 22, IV , da CF/1988 preceitua que cabe privativamente à União legislar sobre "águas, energia, informática, 
telecomunicações e radiodifusão". Adiante, o art. 24, VI, prescreve que compete, concorrentemente, à União, aos Estados e ao Distrito Federal elaborar leis sobre "florestas, caça, pesca, fauna, conservação da natureza, defesa do solo e dos recursos naturais, proteção do meio ambiente e controle da poluição", o que sem dúvida inclui a salvaguarda das águas, na perspectiva da qualidade ambiental. 4. Por sua vez, o art. 23, VI e XI, da CF/1988, de caráter material, atribui aos entes federados (União, Estados, Distrito Federal e Municípios) a competência comum (= competência de implementação) para proteger o meio ambiente, combater a poluição e proceder ao registro, acompanhamento e fiscalização das concessões de direitos de pesquisa e exploração de recursos hídricos e minerais em seus territórios. 5. Todas essas disposições constitucionais se complementam com o art. 225, caput, da Carta Magna, que impõe ao Poder Público e a toda a coletividade o dever de defender e preservar, para as presentes e futuras gerações, o meio ambiente ecologicamente equilibrado, essencial à sadia qualidade de vida, como direito difuso e fundamental, bem de uso comum do povo, vocalizando, em seus comandos normativos, os princípios da precaução, prevenção e reparação integral, entre outros. 6. Logo, na hipótese dos autos, o Estado possui domínio das águas subterrâneas nos precisos termos do art. 20, III, da CF/1988, desde que não se trate de águas subterrâneas federais, isto é, sob terrenos de domínio da União, que banhem mais de um Estado ou sejam compartilhadas com outros países. $E$, mesmo que não fossem de domínio estadual as águas subterrâneas em questão, ainda assim não ficaria limitada a competência ambiental do Estado, seja para legislar sob tal ótica, seja para exercer seu poder de polícia para evitar degradação quantitativa (superexploração e exaustão da reserva) e qualitativa (contaminação dos aquíferos subterrâneos) de recurso natural tão precioso para as presentes e futuras gerações. A multiplicidade e a sobreposição de esferas de controle se justificam pela crescente escassez hídrica, que afeta milhões de brasileiros nas maiores cidades do País e incontáveis outros na zona rural, situação mais preocupante ainda diante de apavorantes previsões de agravamento e calamidade pública na esteira de incontestáveis mudanças climáticas de origem antropogênica. EXAME DO CASO CONCRETO 7. Ao contrário do afirmado na origem, o STJ possui entendimento, em situações análogas, de que o inciso II do art. 12 da Lei 9.433/1997 condiciona a extração de água do subterrâneo à respectiva outorga, o que se explica pela ressabida escassez do bem, considerado como recurso limitado, de domínio público e de expressivo valor econômico (AgRg no REsp 1.352.664/RJ, Rel. Ministro Mauro Campbell Marques, Segunda Turma, DJe 20/5/2013; AgRg no AgRg no REsp 1.185.670/RS, Rel. Min. Benedito Gonçalves, Primeira Turma, DJe 6/9/2011). 8. A interpretação sistemática do art. 45 da Lei 11.445/2007 não afasta o poder normativo e de polícia dos Estados 
no que diz respeito ao acesso às fontes de abastecimento de água e à determinação de conexão obrigatória à rede pública. CONCLUSÃO 9. Recurso Especial provido para julgar improcedente o pedido inicial, com condenação do recorrido ao pagamento das custas processuais e dos honorários advocatícios. (STJ, Acórdão 2011.01.45236-6, Rel. HERMAN BENJAMIN, segunda turma, publicação em 07/11/2016).

Embora essa decisão do STJ já relacionasse a crise hídrica às mudanças climáticas, apresentando como um fato em si e tratando de um recurso estratégico para a humanidade que precisa ser protegido, a água subterrânea, ainda é possível afirmar que essa amplitude fica prejudica por não apresentar um conceito mais abrangente representado pela segurança hídrica, que precisa indicar elementos que remetam à quantidade de água disponível, portanto o acesso à água, que contemple também a qualidade da mesma, se ela apresenta contaminantes, pois não basta ter água, essa água precisa ser segura para a manutenção da vida, sendo uma das condições para que haja desenvolvimento humano, ou seja, um respeito à dignidade humana.

É preciso, outrossim, levar em consideração também critérios de planejamento urbano e rural que possam relacionar a ocupação do solo e a proteção de mananciais contra a má intervenção nesses espaços, como a construção de cidades, de aterros sanitários, de indústrias; a mineração, enfim, qualquer intervenção que possa atuar como contaminante ou prejudicial ao acesso à água segura pelos ecossistemas. O sentido de segurança hídrica deve estar atrelado não só a esses elementos citados, mas à preservação do potencial fornecedor de água aos ecossistemas, deslocando o foco antropocêntrico da proteção para um viés biocêntrico, o que reforçaria as bases de um Estado Ecológico, encarando-se a fornecimento de água como um sistema e não como algo isolado e pertinente apenas às cidades, quando essas últimas usufruem dos serviços ambientais da natureza. Por isso, é necessária uma atualização da lei da $\mathrm{PNRH}$, incluindo critérios para se ter segurança hídrica. 


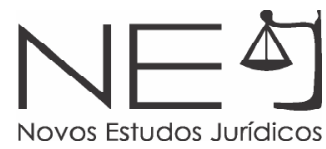

Além disso, é possível encontrar no judiciário decisões que apresentam a escassez hídrica relacionada à baixa geração de energia elétrica ${ }^{49}$, o que dá início a um sistema de bandeiras tarifárias que aumentam o valor das contas desse serviço, fazendo-se uso de um sistema de termelétrica, obsoleto e poluente. Está aí outro critério, a água como geradora de energia, em que a quantidade disponível é essencial para o funcionamento do sistema elétrico. Precisa ter água disponível para a manutenção dos ecossistemas e para a geração de energia por meio de sistemas hidroelétricos, inclusive para a geração de energia nuclear no resfriamento das câmaras onde ocorre a fusão nuclear. Outro elemento é crucial para a formatação de um conceito/instituto de segurança hídrica para a constituição de um Estado de Direito Ecológico, o ciclo da água. Dessa forma, o ciclo da água deve ser entendido como um sistema sócio-eco-hidrológico, cujas interações dos diferentes componentes são permanentemente produzidas, desenvolvendo um estado de equilíbrio dinâmico ${ }^{50}$.

Isso implica no estabelecimento de fluxos ambientais que requerem a consideração das necessidades dos ecossistemas a jusante, tais como zonas úmidas, lagos, planícies, estuários e áreas costeiras e sistemas de águas subterrâneas ${ }^{51}$. Questões culturais, sociais, políticas e econômicas, entre outras, também devem ser consideradas. É necessário adotar uma visão ampla, baseada na gestão integrada dos recursos hídricos, ou seja, não se deve pensar que um manancial está isolado de outros fatores da natureza, bem como de outros repositórios de água, há uma interligação, há um sistema.

Isso fica tanto mais claro à medida que se elabora uma cartografia do problema associada à aplicação das políticas numa dimensão jurídico-ambiental, isto é, é preciso mapear utilizando unidades de análises mais complexas, como "bacia hidrográfica", pensando-se nos múltiplos usos da água e sua relação com os ecossistemas, as cidades, o campo, avaliando suas potencialidades tendo o mapeamento e a sobreposição de mapas como ferramentas de gestão.

49 Superior Tribunal de Justiça, Proc. n. 2018.01.70421-0201801704210, Min. Herman Benjamin; Superior Tribunal de Justiça, Proc. n. 2017.01.66799-0201701667990, Min. Francisco Falcão; Tribunal Regional Federal da Primeira Região, Proc. n. 0022125-98.2017.4.01.000000221259820174010000, Des. Neuza Maria Alves da Silva, 2017; Tribunal Regional Federal da Primeira Região, Proc, n. 0009037-90.2017.4.01.0000 00090379020174010000, Des. Souza Prudente, 2017.

50 UNESCO. Soluciones basadas en la naturaleza para la gestión del agua. Paris: Unesco, 2018.

51 UNESCO. Soluciones basadas en la naturaleza para la gestión del agua. Paris: Unesco, 2018. 
Portanto, a simples noção de falta de água representada pelo tipo jurídico de escassez hídrica não é suficiente para se aquilatar a real complexidade do problema, sendo necessário adotar uma visão sistêmica a partir do ciclo da água num determinado território que envolve a inter-relação de diversos ecossistemas, do contrário haverá dificuldades e prejuízos na tomada de decisão.

Outrossim, é preciso avançar no Direito Ambiental, que deverá considerar de modo mais contundente como unidade de análise de patamares de segurança hídrica, a "bacia hidrográfica", e até que ponto o comprometimento dessa unidade geográfica pode atingir os fatores relacionados com segurança hídrica, aproximando-se o máximo possível da percepção da sustentação de sistemas de vida animal e vegetal, macro e microscópicas, sendo a água essencial para isso.

Outro ponto a ser ponderado é o direito intergeracional ao meio ambiente de qualidade e saudável, que deve ser a base, também, para a formulação de um conceito jurídico de segurança hídrica, uma vez que, ao se consumir a água proveniente de diversas fontes superficiais e subterrâneas, ou a comprometer-se o ciclo da água, está-se prejudicando as gerações vindouras.

Por isso que um conceito/instituto de segurança hídrica deve levar em consideração a quantidade que se está utilizando, os múltiplos usos da água, a reposição da mesma e a reserva e a proteção para a atual e futuras gerações, considerando que a população mundial triplicou o consumo de água, principalmente para a produção de alimentos, que sextuplicou ${ }^{52}$.

A estimativa é que 54 países estarão enfrentando escassez severa de água, por volta do ano de 2050, e a projeção da população atingida poderá chegar a 4 bilhões de habitantes, cerca de $40 \%$ da população mundial, com especial atenção para o continente africano e o Oriente Médio ${ }^{53}$. O mapa 1 apresenta o nível de estresse hídrico, ou seja, o nível de escassez de água ou de disponibilidade hídrica.

52 AGÊNCIA NACIONAL DE ÁGUAS. Água na medida certa: a hidrometria no Brasil / Agência Nacional de Águas; textos elaborados por Antonio Cardoso Neto. Brasília: ANA, 2012.

53 AGÊNCIA NACIONAL DE ÁGUAS. Água na medida certa: a hidrometria no Brasil / Agência Nacional de Águas; textos elaborados por Antonio Cardoso Neto. Brasília: ANA, 2012. 


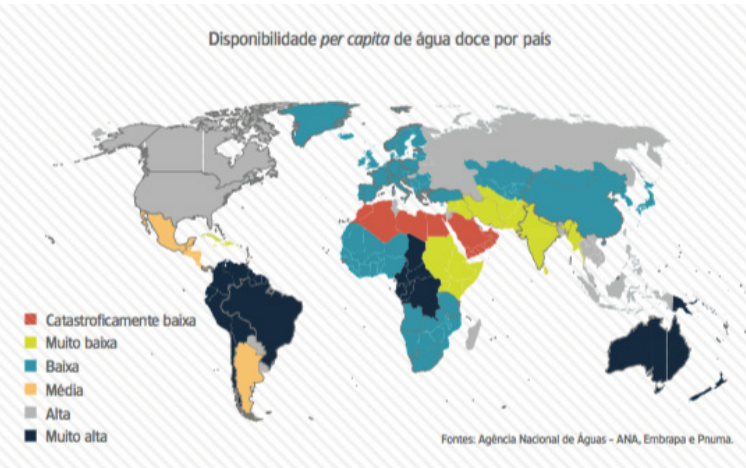

Mapa 1 - Disponibilidade Hídrica

É fundamental destacar que a produção de alimentos está diretamente ligada à disponibilidade e ao uso de água. Por exemplo, para a produção de 1 quilograma de arroz, um dos cereais mais consumidos no mundo, utiliza-se de 1000 a 3000 litros de água, de sua germinação até a colheita; de 1 quilograma de carne bovina, usa-se entre 13000 a 15000 litros de água ${ }^{54}$. Portanto, os patamares de segurança hídrica também devem estar relacionados à produção de alimentos.

Outro indicador que precisa constar da concepção de segurança hídrica é a quantidade de água mínima necessária para a manutenção da vida. Por exemplo, uma pessoa necessita cerca de 2 a 4 litros de água diariamente, e para sua alimentação básica diária entre 2000 a 5000 litros por dia. Entretanto, 2,1 bilhões de pessoas no mundo não têm acesso à água potável, e mais do dobro não têm saneamento seguro em casa, tendo um reflexo direto no aumento de doenças relacionadas com a ausência, ou acesso precário a esses serviços básicos. Isso faz pensar na necessidade de se assegurar a qualidade de vida, portanto, a dignidade humana, a partir de patamares plausíveis de segurança hídrica.

Porém, o panorama de mudanças climáticas no Planeta afeta diretamente esses fatores relacionados com a segurança hídrica, diminuindo a disponibilidade de água, por exemplo, para a produção de alimentos ${ }^{55}$. Além disso, o aumento do uso de fertilizantes para a produção de alimentos provoca uma grande descarga de nitrogênio nas águas de rios e mares, inviabilizando ecossistemas essenciais.

54 AGÊNCIA NACIONAL DE ÁGUAS. Água na medida certa: a hidrometria no Brasil/Agência Nacional de Águas; textos elaborados por Antonio Cardoso Neto. Brasília: ANA, 2012.

55 AGÊNCIA NACIONAL DE ÁGUAS. Água na medida certa: a hidrometria no Brasil/Agência Nacional de Águas; textos elaborados por Antonio Cardoso Neto. Brasília: ANA, 2012. 
Destaque-se que a legislação brasileira já aborda o tema da segurança no que se refere aos alimentos, com a expressão segurança alimentar, relacionando-a à alimentação adequada. Assim dispõe:

Art. 2. A alimentação adequada é direito fundamental do ser humano, inerente à dignidade da pessoa humana e indispensável à realização dos direitos consagrados na Constituição Federal, devendo o poder público adotar as políticas e ações que se façam necessárias para promover e garantir a segurança alimentar e nutricional da população. (Lei n. 11.346/2006)

Além disso, estabelece uma definição jurídica acerca dessa expressão levando em consideração múltiplos fatores, inclusive ecológicos.

Art. 3. A segurança alimentar e nutricional consiste na realização do direito de todos ao acesso regular e permanente a alimentos de qualidade, em quantidade suficiente, sem comprometer o acesso a outras necessidades essenciais, tendo como base práticas alimentares promotoras de saúde que respeitem a diversidade cultural e que sejam ambiental, cultural, econômica e socialmente sustentáveis.

Veja-se que, ao definir segurança alimentar, o legislador levou em conta uma multiplicidade de fatores essenciais para se ter uma qualidade alimentar, com disponibilidade, sem agrotóxicos, cultivado com técnicas sustentáveis, enfim, não sendo suficiente o alimentar-se em si, mas que o alimento seja seguro, e as quantidades mínimas para a concretização do direito humano a uma alimentação saudável sejam providenciadas. É importante mostrar aqui nesse espaço a abrangência do conceito de segurança alimentar e nutricional, inclusive como paradigma para se cunhar um conceito de segurança hídrica.

Art. 4. A segurança alimentar e nutricional abrange:

I. a ampliação das condições de acesso aos alimentos por meio da produção, em especial da agricultura tradicional e familiar, do processamento, da industrialização, da comercialização, incluindose os acordos internacionais, do abastecimento e da distribuição dos alimentos, incluindo-se a água, bem como da geração de emprego e da redistribuição da renda; 


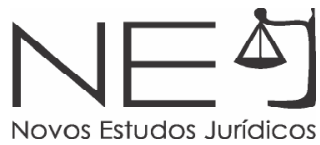

II. a conservação da biodiversidade e a utilização sustentável dos recursos;

III. a promoção da saúde, da nutrição e da alimentação da população, incluindo-se grupos populacionais específicos e populações em situação de vulnerabilidade social;

IV. a garantia da qualidade biológica, sanitária, nutricional e tecnológica dos alimentos, bem como seu aproveitamento, estimulando práticas alimentares e es los de vida saudáveis que respeitem a diversidade étnica e racial e cultural da população;

V. a produção de conhecimento e o acesso à informação; e

VI. a implementação de políticas públicas e estratégias sustentáveis e participativas de produção, comercialização e consumo de alimentos, respeitando-se as múltiplas características culturais do País.

No Brasil, portanto, não se tem parâmetro quanto à segurança hídrica, aproximando-a à mera garantia de abastecimento de água, quando na verdade vai muito mais além, envolvendo quantidade, qualidade, uso e ocupação do solo, preservação dos ecossistemas, preservação das nascentes, preservação dos aquíferos, eliminação do uso de agrotóxicos, controle e diminuição da poluição, forte controle da atividade minerária, controle dos resíduos sólidos, mitigação das causas das mudanças climáticas, enfim, uma série de fatores que demonstram a complexidade que suplanta a mera garantia do combate à escassez de água.

Essa é uma realidade vivenciada, por exemplo, no semiárido nordestino, em que as mudanças climáticas têm modificado os ciclos de períodos chuvosos, tornando as secas mais prolongadas, e o que tem sido proposto é mais do mesmo, grandes obras de infraestrutura hídrica ${ }^{56}$, abastecimento por carrospipa, cisternas, não se negando a utilidade emergencial de todas essas soluções, porém são soluções não integradas com as diretrizes de um Estado Ecológico de Direito.

56 SILVA, J. I. A. O. RESSIGNIFICAÇÃO AMBIENTAL E MODERNIZAÇÃO ECOLÓGICA NO SEMIÁRIDO: O Projeto de Integração e a revitalização do São Francisco. 1. ed. SÃO PAULO: HUCITEC, 2016. 
Entretanto, o que se está defendendo é que o estabelecimento de uma segurança hídrica como instituto jurídico concederia parâmetros mais claros para uma intervenção maior dos órgãos reguladores, judiciário e ministério público, indo além, mergulhando num patamar ecológico da água.

No caso brasileiro, tem-se uma lei paradigma para um ponto de partida, notadamente a definição de segurança alimentar e seus requisitos, que vão muito além de uma mera escassez alimentar, inclusive deve se relacionar com a segurança hídrica, uma vez que água e alimentação estão intimamente interligadas. Não se advoga mais um diploma legal para não ser cumprido em termos de proteção ambiental, porém a inexistência de um instituto jurídico da segurança hídrica não traz sistematicidade para a discussão, inclusive para dar amparo aos órgãos formuladores de políticas públicas, aos que executam e aos que fiscalizam e regulam.

\section{CONCLUSÕES}

Ao longo do texto ficou caracterizada a existência de uma crise da contemporaneidade que envolve a necessidade de mudança de paradigmas, em que é difícil garantir a segurança em face da escassez de diversos bens ambientais, dentre eles, a água. É possível assegurar água em quantidade, em qualidade e suficiente para a manutenção da vida no Planeta, representada pelos ecossistemas?

Essa é uma pergunta cuja resposta é difícil de ser dada com precisão, levando-se em conta a fluidez do próprio vocábulo segurança, que varia no tempo e no espaço, não sendo razoável, portanto, restringir, ou se aproximar, a segurança hídrica da escassez, estabelecendo parâmetros para baixa escassez, média ou alta, quando se prevê a possibilidade de uma situação em que se terá quantidade de água, porém com qualidade duvidosa. Além disso, é importante, pontificar o que se quer assegurar, a quem se destina a segurança, o que pode mudar substancialmente num contexto antropocêntrico ou biocêntrico. O direito humano à água e o direito ao saneamento básico fazem parte da base necessária para a concretização da dignidade humana como princípio maior que caracteriza 


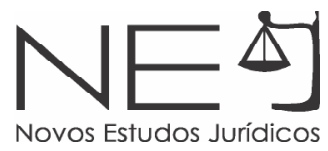

os atributos de um ser humano individual e coletivamente em sociedade. Dessa forma, como se pensar numa sociedade justa, se boa parte da população não tem água suficiente para sobreviver ou mesmo não tem o esgoto tratado que previne a população de doenças graves, ainda muito populares, principalmente nos países pobres ou em desenvolvimento. Entretanto, o escopo do texto foi demonstrar a existência de uma lacuna na legislação que estabelece a Política Nacional de Recursos Hídricos, num contexto de necessidade de mudança de paradigmas e, principalmente, mudança do atual modelo de Estado permissivo e deletério dos recursos naturais, para um Estado protetor dos recursos naturais, que não mercadeje a vida no Planeta, ou seja, um Estado de Direito Ecológico.

Pensa-se numa acepção de segurança que suplante a compreensão de mera proteção das pessoas, mas que amplie esse espectro para além da proteção dessas, a proteção de ecossistemas, e pergunta-se: qual proteção? Que tipo de proteção é necessária e possível? Entretanto, defende-se que, para que haja uma segurança hídrica ampla é fundamental estabelecer parâmetros na política e não a restringir apenas a escassez. É necessário pensar em segurança hídrica em termos de ciclo hidrológico e tudo que o envolve.

É possível lembrar se das normas do Conselho Nacional de Meio Ambiente (CONAMA) ${ }^{57}$ que estabelecem parâmetros claros quanto à possibilidade de lançar resíduos dos efluentes nos mananciais, córregos, rios, mares, existindo ainda pontos cinzentos quanto às águas subterrâneas na legislação, sendo primordial a eliminação desses pontos cinzentos, que se estendem também para o sentido de segurança hídrica. Como estabelecer uma segurança hídrica ecológica ainda sendo possível lançar esgoto em corpos de água? Isso tudo precisa ser considerado quando do estabelecimento da segurança hídrica na PNRH à luz das mudanças climáticas, instituída pela Lei n. 11.433/1997, uma vez que hoje não há parâmetro jurídico. Não se tem uma relação clara entre segurança hídrica e mudanças climáticas em termos de legislação, embora se saiba a importância do ciclo hidrológico em relação às mudanças climáticas, bem como o impacto da falta ou baixa segurança hídrica para essas.

57 Resoluções n. 5/1988; n. 430/2011. 
É importante deixar claro em sede de conclusões que o que se está a propor é a formulação de um instituto jurídico baseado em princípios orientadores, que não teria natureza estática, visto que não é possível pontificar para todas as épocas da história um padrão único de segurança, variando no tempo e no espaço. Sabe-se que se vivencia um contexto de crescente risco e, portanto, um aumento da dificuldade em se conceder segurança de modo amplo para a sociedade.

Porém, é possível estabelecer-se, como se fez com a segurança alimentar, conteúdo conceitual em face da expressão segurança hídrica, uma vez que até agora não há parâmetros na lei que balizem as decisões. Porém, entende-se que maior risco se corre ao não se parametrizar juridicamente a segurança hídrica, que precisa ser monitorada e compreendida a cada momento da história, a partir de um contexto de mudanças climáticas. Dessa forma, a mudança de paradigma, que dará sustentação ao Estado de Direito Ecológico, passará essencial pela definição de um instituto jurídico que demarque de forma ampla o que significa segurança hídrica num viés ecológico.

\section{REFERÊNCIAS DAS FONTES CITADAS}

ALIER, Joan Marínez. $\mathbf{O}$ ecologismo dos pobres: conflitos ambientais e linguagens de valoração. São Paulo: Contexto, 2007.

AGÊNCIA NACIONAL DE ÁGUAS. Água na medida certa: a hidrometria no Brasil / Agência Nacional de Águas; textos elaborados por Antonio Cardoso Neto. Brasília: ANA, 2012.

ARAGÃO, Alexandra. O Estado de Direito Ecológico no Antropoceno e os limites do Planeta. In Dinnebier, Flávia França (Org.). Estado de Direito Ecológico: Conceito, Conteúdo e Novas Dimensões para a Proteção da Natureza./ Flávia França Dinnebier (Org.); José Rubens Morato Leite (Org.); - São Paulo : Inst. O direito por um Planeta Verde, 2017.

ASWATHANARAYANA, Uppugunduri. How to do with less water. In Aswathanarayana, $U$. (Coord.). Food and water security. London: Taylor \& Francis, 2007.

BAUMAN, Zygmunt. Modernidade e ambivalência. Rio de Janeiro: Jorge Zahar, 1999.

BIAZATTI, Bruni de Oliveira, PEREIRA, Luciana Diniz Durães. Aspectos Principiológicos acerca da Necessidade de Proteção dos "Refugiados Ambientais": Por uma Nova Hermenêutica do Sistema Jurídico Internacional. In JUBILUT, Lilian Lyra, RAMOS, Érika Pires, CLARO, Carolina de Abreu Batista, CAVEDON-CAPDEVILLE, Fernanda de Salles (Orgs). Refugiados ambientais. Roraima: Editora da UFRR, 2018. 


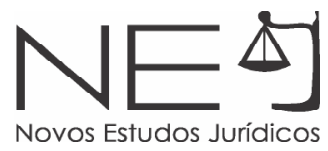

BECK, Ulrich. La sociedad del riesgo: hacia una nueva modernidad. Barcelona, Paidós, 2006.

BOLLIER, David, WESTON, Burns H. Green Governance ecological survival, human rights, and the law of the commons. New York: Cambridge University Press, 2013.

BOYED, David R. The Rigths of Nature: A Legal Revolution that Could Save the World. Toronto: ECW Press, 2017.

BRUCKMANN, Mónica. Recursos naturales y la geopolítica de la integración sudamericana. Instituto Perumundo; Fondo Editorial J.C.Mariátegui, 2012.

BULTO, Takele Soboka. Muito familiar para ignorar, muito novo para reconhecer: a situação do direito humano à água em nível global. In CASTRO, Jose Esteban, HELLER, Léo, MORAIS, Maria da Piedade. O direito à água como política pública na América Latina: uma exploração teórica e empírica. Brasília: IPEA, 2015.

CAPRA, Fritjof; MATTEI, Ugo. The Ecology of Law. Okland: BK. 2015.

CASTRO, Jose Esteban. $\mathbf{O}$ acesso universal à água é uma questão de democracia. In Boletim Regional, Urbano e Ambiental no 15, Julho/Dezembro 2016 .

Água e democracia na América Latina. Campina Grande: EDUEPB, 2016b.

CAVEDON-CAPDEVILLE, Fernanda de Salles. Jurisprudência ecologizada nas cortes de direitos humanos: contribuições para a ecologização dos direitos humanos. In LEITE, José Rubens Morato. A ecologização do direito ambiental vigente. Rio de Janeiro: Lumen Juris, 2018.

CAVEDON-CAPDEVILLE, Fernanda de Salles. O Projeto de Convenção de Limoges sobre o Estatuto Internacional dos Deslocados Ambientais. In JUBILUT, Lilian Lyra, RAMOS, Érika Pires, CLARO, Carolina de Abreu Batista, CAVEDON-CAPDEVILLE, Fernanda de Salles (Orgs). Refugiados ambientais. Roraima: Editora da UFRR, 2018.

DARDOT, Pierre, LAVAL, Christian. A nova razão do mundo: ensaios sobre a sociedade neoliberal. São Paulo: Boitempo, 2016.

FELIX, Ricardo Burrattino. Bangladesh: Vulnerabilidade Ambiental e a Vida Humana. In JUBILUT, Lilian Lyra, RAMOS, Érika Pires, CLARO, Carolina de Abreu Batista, CAVEDONCAPDEVILLE, Fernanda de Salles (Orgs). Refugiados ambientais. Roraima: Editora da UFRR, 2018.

FERREIRA, Helini Sivini. Desvendando os organismos transgênicos: as interferências da sociedade de risco no Estado de Direito Ambiental. Rio de Janeiro: Forense Universitária, 2010.

GIDDENS, Anthony. As conseqüências da modernidade. São Paulo: Editora da UNESP, 1991. 
HARVEY, David. 17 contradições e o fim do capitalismo. São Paulo: Boitempo, 2016.

ISLA, Ana. The "greening" of Costa Rica: women, peasants, indigenous people and the remaking nature. Canadá: University of Toronto Press, 2015.

LEFF, Henrique. Racionalidade ambiental: a reapropriação social da natureza. Rio de Janeiro: Civilização Brasileira, 2006.

LEFF, Henrique. Diálogos de saberes, saberes locales y racionalidad ambiental en la construcción social de la sustentabilidad. In SÁNCHEZ, A. L. Governabilidad y desarrolho sustentable: miradas múltiples. México: UNAM, 2012.

LEITE, José Rubens Morato, SILVEIRA, Paula Galbiatti. BETTEGA, Belisa. O Estado de Direito para a natureza: fundamentos e conceitos. In Dinnebier, Flávia França (Org.). Estado de Direito Ecológico: Conceito, Conteúdo e Novas Dimensões para a Proteção da Natureza./ Flávia França Dinnebier (Org.); José Rubens Morato Leite (Org.); - São Paulo : Inst. O direito por um Planeta Verde, 2017.

LENZI, Cristiano Luis. Sociologia ambiental: risco e sustentabilidade na modernidade. São Paulo, Bauru: Edusc, 2006.

MENDES, José Manuel. Ulrich Beck: a imanência do social e a sociedade do risco. In Análise Social, 214, I (1.), 2015.

MOTTA, Renata. Sociologia de risco: globalizando a modernidade reflexiva. In. Sociologias, Porto Alegre, ano 11, no 22, jul./dez. 2009, p. 384-396.

OROZCO, Jose Luis. Esperando a Trump: Los antecedentes históricos del "nuevo viraje" norteamericano. México: Universidad Nacional Autónoma de México, 2017.

PORTO, Marcelo Firpo de Souza. Uma ecologia política dos riscos. Rio de Janeiro: editora Fiocruz, 2007.

RIBEIRO, Ricardo Lodi. Globalização, Sociedade de Risco e Segurança. Revista de Direito Administrativo, Rio de Janeiro, v. 246, p. 267-287, set. 2007. ISSN 2238-5177. Disponível em: <http://bibliotecadigital.fgv.br/ojs/index.php/rda/article/view/41660>. Acesso em: 12 Fev. 2019. doi:http://dx.doi.org/10.12660/rda.v246.2007.41660.

SHIVA, Vandana. Las guerras del agua: privacización, àcontaminación y lucro. Mexico: Siglo XXI editores, 2007.

SILVA. José Irivaldo Alves Oliveira. RESSIGNIFICAÇÃO AMBIENTAL E MODERNIZAÇÃo ECOLÓGICA NO SEMIÁRIDO: O Projeto de Integração e a revitalização do São Francisco. 1. ed. SÃO PAULO: HUCITEC, 2016.

UNDP. Governance for Sustainable Human Development, A UNDP Policy Document. UNDP, New York, 1997. 
VEYRET, Yvette. Os riscos: o homem como agressor e vítima do meio ambiente. São Paulo: editora Contexto, 2007.

WOLF, Aaron T., STEFANO, Lucia de, SVENDSEN, Mark, GIORDANO, Mark, STEEL, Brent S., BROWN, Bridget. Water governance benchmarking: concepts and approach framework as applied to Middle East and North Africa countries. In Water Policy 16, 1121-1139, 2014.

World Bank. Strengthening World Bank Group Engagement on Governance and Anticorruption. Joint Ministerial Committee of the Boards of Governors of the Bank and the Fund on the Transfer of Real Resources to Developing Countries, Washington, DC, 2007.

UNESCO. Soluciones basadas en la naturaleza para la gestión del agua. Paris: Unesco, 2018

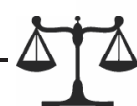

